\title{
What are the opportunities for manufacturing in the "one belt one road" initiative? The case of Hong Kong's textiles and clothing sector
}

\begin{abstract}
The One Belt, One Road (OBOR) initiative, also known as the Belt and Road Initiative (BRI), is a development strategy launched by China in 2015. The aim is to increase economic co-operation among countries along the Silk Road Economic Belt and the 21 st Century Maritime Silk Road that connect Asia, Europe and Africa. This study investigates how Hong Kong can strengthen its "super-connector" role by facilitating sustainable trade and development in the textile and clothing (T\&C) industries among some of the OBOR countries. The study extends the gravity trade model to analyze the T\&C trade between Hong Kong and the OBOR countries. Specifically, the study considers the role of logistics and demographic factors, especially those that are related to the business environment and policies that have not been considered in the literature. The analysis results are then applied to discuss how T\&C companies in Hong Kong can establish and facilitate technological upgrades and transformation of potential production facilities in some of the developing countries under the OBOR initiative. This would contribute to the sustainable development of the T\&C sectors in Hong Kong. Further recommendations are also provided to discuss how Hong Kong may help to facilitate trade and development of the T\&C sectors under the OBOR initiative.
\end{abstract}

Keywords: one belt, one road (obor), bell road initiative (bri), impact of logistics performance $\mathrm{n}$ trade, gravity model
Volume 4 Issue 6 - 2018

\author{
Man Hin Eve Chan, ' Wai Ching Alice Chu,' \\ Yui-yip Lau, ${ }^{2,3}$ Chi Kuen Danny Ho, ${ }^{4}$ and \\ Hong-Oanh Nguyen ${ }^{5}$ \\ 'Faculty of Design and Environment, Technological and Higher \\ Education Institute, Hong Kong \\ ${ }^{2}$ Hong Kong Community College, Hong Kong Polytechnic \\ University, Hong Kong \\ ${ }^{3}$ Transport Institute, University of Manitoba, Winnipeg, Manitoba, \\ Canada \\ ${ }^{4}$ Department of Supply Chain and Information Management, \\ Hang Seng University of Hong Kong, Hong Kong \\ ${ }^{5}$ Department of Maritime and Logistics Management, University \\ of Tasmania, Australia
}

Correspondence: Hong-Oanh Nguyen, Department of Maritime and Logistics Management, University of Tasmania, Australia,Tel +6I 36324 9762, Email o.nguyan@utas.edu.au

Received: November 01, 2018 | Published: November 12, 2018

\section{Background}

The One Belt One Road (OBOR) initiative is a development strategy launched by China in 2015. Its main objective is to promote economic co-operation among countries in Asia, Europe and Africa that are found along the belt (the "Silk Road Economic Belt" which stretches from China to Central Asia, Russia and Europe), and the road (the "21st Century Maritime Silk Road" which spans from China to Europe through the South China Sea and Indian Ocean, and from China though the South China Sea to the South Pacific). Since 2013, over 30 OBOR proposals for cooperation and implementation agreements have been developed, together with definitions of the core areas of cooperation, and well-defined details for the key framework and cooperation mechanisms. In general, the initiative contains six international economic cooperation corridors, including key transport routes and important cities. ${ }^{1}$ Due to its strategic location with convenient access to the Southeast Asia and Pacific countries, and strength in financial services and technology, Hong Kong is expected to substantially benefit from the initiative. For example, Hong Kong banks could provide financing services for OBOR infrastructure projects and trading companies could expand their markets and have better access to countries in the OBOR region. Hong Kong manufacturing companies can also benefit from technology transfer and invest in countries which have relatively lower labor costs.

There is often a high demand from the labor-intensive industries in Hong Kong for new low-cost offshore production sites, which is particularly the case for the T\&C sectors. Since the 1980s, T\&C companies in Hong Kong have been relocating to mainland China and expanding their production facilities there, as well as in other countries such as Bangladesh, Cambodia, Vietnam and Sri Lanka. This strategy helps to expand production at lower costs and reap the benefits from trade preferential access agreements for the EU and US markets. The strategy of relocating the production of lower-end and mass garments to places with a cheaper labor supply seems to underpin the historical development of some of these T\&C companies that position themselves as the original equipment manufacturing (OEM) package contractors for foreign brand owners and retailers.

On the other hand, the partnering countries of the OBOR initiative will present themselves as an attractive venue for foreign investments in trade-led manufacturing. This is because infrastructure quality and quantity affect the attractiveness of a country as an offshore production location, and thus its opportunity to integrate with global and regional production chains. In their meta-analysis of 36 empirical trade studies, Celbis et al. $^{2}$ reported that there is a significantly positive impact between export performance and infrastructure. With the use of gravity trade model, Hoekman \& Nicita $^{3}$ found that domestic trading costs represent import and export bottlenecks for low income countries. Using a standard gravity trade model, Shepherd \& Wilson ${ }^{4}$ reported that "trade flows in Southeast Asia are particularly sensitive to transport infrastructure and information and communications technology", and suggested that "the region could make significant economic gains from trade facilitation reform". Pomfret $^{5}$ observed that Cambodia, Laos and Myanmar, as the new members of the Association of Southeast Asian Nations (ASEAN), are not able to match the performance of the earlier ASEAN members 
in the integrated East Asian economy. That is partly due to their high trade costs which create barriers that impede their active participation in regional value chains Pomfret. ${ }^{5}$

One can expect that the OBOR initiative has a role in helping developing countries to improve their infrastructure for trade as well as enable some of the $\mathrm{T} \& \mathrm{C}$ companies in Hong Kong to pursue future production relocation. However, this model of development will only encourage companies to keep relocating low-value added production processes to locations with lower costs, and put pressure on developing countries to keep their domestic production and trade costs as low as possible to attract foreign investments. As Ross \& $\mathrm{Chan}^{6}$ showed, during the transition from the North-South to South-South competition in the production of labor-intensive commodities since 2000, Mexico lost its low-cost competitive advantage vis-à-vis China, and between 2000 and 2002, approximate 28,000 jobs in Mexico's maquiladoras were lost. Competition for international capital is fierce not only at the country level, but also among provinces within a country. In their study of 2,884 firms that invested in China between 1993 and 1996, Liu et al. ${ }^{7}$ reported that foreign investors are highly sensitive to provincial wage differences in finalizing their decision on the location of $\mathrm{T} \& \mathrm{C}$ industries, among other labor intensive industries. It is no surprise that export-oriented manufacturers who pursue geographical relocation of low value added production processes might take advantage of the OBOR initiative. This could, on the one hand, further accelerate the "race to the bottom" in labor welfare in the T\&C sectors of developing countries. On the other hand, this exacerbates the negative consequences resultant of the end of the quotas system in textiles and clothing $(\mathrm{T} \& \mathrm{C})$ products since $2005 .^{8}$

There are two main objectives of this paper. First, the work extends the trade gravity model to analyze the development of T\&C trade patterns between Hong Kong and the OBOR countries. Second, the study investigates how Hong Kong can take advantage of its "superconnector" role in facilitating sustainable trade and development in the $\mathrm{T} \& \mathrm{C}$ industries in the OBOR countries.

\section{Quest for a sustainable development model in the T \& C industries}

Due to its strategic location in Southeast Asia and technological advantage, Hong Kong can have a 'super-connector' role in driving the T\&C sectors in both China and the OBOR countries. This can be achieved from at least three aspects. First, due to its location and better access to international transport and logistics services, Hong Kong has a cost advantage and hence more competitiveness than the producers in other countries. Contrary to the common view that international buyers take the lead to upgrade their supply chains, Au $\& \mathrm{Ho}^{9}$ noted that it is actually the Hong Kong manufacturers who have played a proactive role in pursuing supply chain excellence by applying new technologies and practices over the years. This is plausible because most international brand-name retailers do not own or operate production facilities, and thus rely heavily on highly capable full-package suppliers.

Second, due to its cumulative knowledge in product management, marketing and market access, Hong Kong can serve as a distribution hub for T\&C products produced from OBOR countries and export the goods to the rest of the world. Companies in Hong Kong can take on a central role in the design, production and distribution of products produced from OBOR countries and distribute them to the rest of the world, especially the markets in developed countries, where Hong Kong has a better understanding of consumer preferences and can access the distribution networks. According to $\mathrm{Ho},{ }^{10}$ some T\&C companies in Hong Kong have established in-house training and development programs that aim to enhance technical skills for critical production roles, with pilot programs conducted in factories in China and Malaysia and later expanded to all factories in the Asia region. With advanced knowledge and skills, the trainees are empowered and enabled to implement different projects that boost production efficiency and quality. These practices help to reduce the pressure caused by rising labor costs due to the relocation of production facilities, and offer opportunities to pursue higher-value activities. Social upgrades in developing countries are also made possible through the transfer of successful training and development programs to new production facilities, with the aim to improve labor skills and welfare in a shorter amount of time. ${ }^{11}$

Third, Hong Kong can play a key role in foreign investment and technology transfer for the development of the T\&C sector in the OBOR countries. T\&C companies in Hong Kong may also invest in developing new technologies and practices in the more mature and advanced production facilities, so as to offset higher labor costs through productivity gain and better product quality. This strategy offers opportunities for technology transfer and knowledge sharing with the new production base, thus contributing as industry upgrades in the host countries. At the same time, these new technologies and practices are highly eco-efficient, for example, the denim program of $\mathrm{H} \& \mathrm{M}$ aims to improve water-efficiency and thus has fewer negative environmental impacts. ${ }^{12}$

Fourth, the past few years have witnessed an increasing awareness of corporate social responsibility (CSR) and sustainable development that are tied to safety management, environmental impacts, and community engagement. As a result, large fashion companies have been managing their operations in a more socially and environmentally responsible way. ${ }^{12}$ Large Hong Kong T\&C manufacturers are in joint collaborations with their international buyers and non-governmental organizations to implement various training and development programs for workers, with the aim to expand their network relations as well as encourage occupational health and safety in their new factories in the Southeast Asia region. ${ }^{10}$ It is therefore expected that $\mathrm{T} \& \mathrm{C}$ suppliers in the developing countries will follow the same trend.

\section{Extended gravity model of $T$ \& $C$ trade between Hong Kong and OBOR countries}

This section is a discussion on the T\&C trade between Hong Kong and the Asian countries that are now member countries of the OBOR initiative. The well-known gravity model of international trade is extended and applied to investigate $\mathrm{T} \& \mathrm{C}$ trade among the OBOR countries. The model attributes trade between two countries to the size of their economies and distance between them, hence the 'gravity' model. ${ }^{13,14}$ Moreover, the model performs well in empirical research. ${ }^{15,16}$ Apart from its use in empirical studies, the gravity trade model has been used as a means to test different trade theories, such as by Anderson, ${ }^{17}$ Bergstrand ${ }^{18}$ and Eli Heckscher and Bertil Ohlin ${ }^{19}$ because it can be extended to account for the effect of various factors on international trade.

In this study, the extended model covers other factors that have not been considered in previous studies on the same sectors, such as 
production costs, export supply chain costs, technologies, demographic factors, and the characteristics of the business environment and policies. The analysis made use of panel data and allowed for fixed effects over time for each scenario, thus exploring the changes and increasing the manipulation of the data quality and quantity which would otherwise not be possible with the use of cross sectional or time series estimation alone. The analysis included the impact of transport and logistics by using the Logistics Performance Index (LPI), country-specific and social determinants as well as economic indicators influential to T\&C trade (Figure 1).

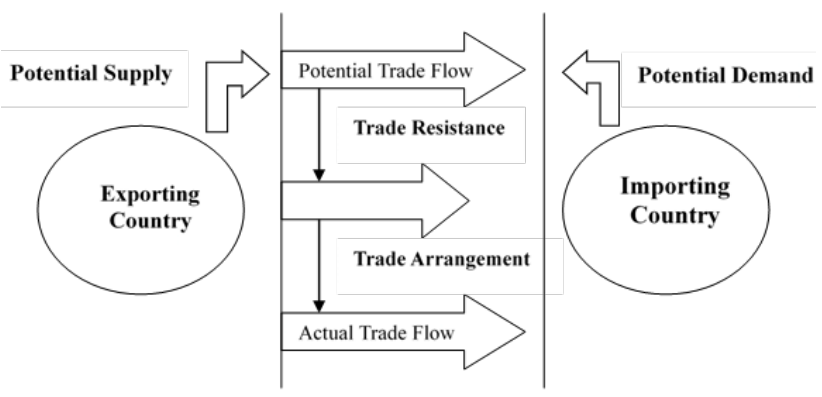

Figure I Trade Gravity Model.

Source: Polder. ${ }^{20}$

Following Lau, Chan, and Nguyen (2017), we propose the following extension of the gravity model:

$\ln \left(\mathrm{EXP}_{i j}\right)_{t}=\alpha+\beta_{1} \ln \left(\mathrm{GDP}_{i}\right)_{t}+\beta_{2} \ln \left(\mathrm{PCGDP}_{i}\right)_{t}+\beta_{3} \ln \left(\mathrm{GPD}_{j}\right)_{t}+$ $\beta_{4} \ln \left(\mathrm{PCGDP}_{j}\right)_{t}+\beta_{5} \ln \left(\mathrm{D}_{i j}\right)+$

$$
\beta_{6} \ln \left(\mathrm{POP}_{j t}\right)+\beta_{7} \operatorname{REXRATE}_{i j t}+\beta_{8} \operatorname{In}\left(\mathrm{VALADDED}_{i}\right)_{t}+\beta_{9} \operatorname{In}\left(\mathrm{WAGE}_{i}\right)
$$$$
+
$$$$
\beta_{10} \operatorname{In}\left(\text { FEMALE }_{i}\right)_{t}+\beta_{11}\left(\operatorname{LPI}_{i}\right)_{t}+\mathrm{U}_{i j t^{\prime}}
$$

Where

a. $\ln \left(\mathrm{EXP}_{i j}\right)_{t}-\log$ of $\mathrm{T} \& \mathrm{C}$ export value in USD (millions) from OBOR countries to Hong Kong, with $i$ denoting the exporting country, $j$ Hong Kong, and $t$ the annual period from 2005 to 2015

b. $\quad \alpha$ - fixed effect that represents unobserved time-constant factors on $\mathrm{EXP}_{i j}$

c. $\beta$ - coefficient

d. $\ln \left(\mathrm{GDP}_{i}\right)_{t}-\log$ of GDP of the exporting country in USD (millions)

e. $\ln \left(\mathrm{GDP}_{j}\right)_{t}-\log$ of GDP of the importing country in USD (millions)

f. $\ln \left(\mathrm{D}_{i j}\right)-\log$ of geographical distance (in $\mathrm{km}$ ) between the individual capitals of the importing and exporting countries

g. $\mathrm{U}_{i j t}$ - error term

h. (for the extension of the independent variables)

i. $\ln \left(\mathrm{PCGDP}_{i}\right)_{t}-\log$ of GDP per-capita of the exporting country in USD (millions)

j. $\quad \ln \left(\mathrm{PCGDP}_{\mathrm{j}_{t}}\right)_{t}-\log$ of GDP per-capita of the importing country in USD (millions)

k. $\ln \left(\mathrm{POP}_{j i}\right)-\log$ of the population of the importing country
1. REXRATE Ritt - real exchange rate in terms of value of foreign currency per USD

m. In(VALADDED $)_{i}$ - log of the value added in the apparel industry of the exporting country

n. In(WAGE $)_{j}-\log$ of the wages of the exporting country in millions of USD;

o. In(FEMALE $)$ - $\log$ of the number of women in the work force of the exporting country

p. LPI $_{i t}$ - the Logistics Performance Index of the exporting country.

The dependent variable is the log of the $\mathrm{T} \& \mathrm{C}$ trade value between Hong Kong as the importing country and OBOR exporting countries including Bangladesh, Cambodia, India, Indonesia, Malaysia, Pakistan, the Philippines, South Korea, Sri Lanka, Taiwan, Thailand and Vietnam. The independent variables include the log of the total exports from country $i$ to country $j, \log$ of GDPs of the two countries, log per capita GDPs of the two countries, distance between them, log of population size of importers, real exchange rate, log of value added factors, the number of women in the workforce, and labor costs of the exporters.

Since the economic size of the exporting and importing countries is usually measured by the GDP, the GDPs of the importing country and their apparel exporters are considered to represent the economic masses which impact the apparel exports of the country's economy. As GDP also indicates the supply capability of the apparel exporting countries, $\beta_{1}$ and $\beta_{3}$ are expected to be positive.

Based on the gravity principle, the per-capita GDP of the exporting country is used as a proxy of capital intensity. As the apparel industry is labor-oriented, per-capita GDP is used to indicate the impact of the monetary conditions on the workforce in countries with apparel exports. Additionally, the income level or purchasing power of importing countries is represented by the per capita GDP. Controlling for the GDP, richer countries (in terms of their per capita GDP) are likely to demand more choices in different products which may be imported from countries that specialize in the production of such products. Therefore, $\beta_{2}$ and $\beta_{4}$ are expected to be positive.

The distance variable has proven to be one of the most significant variables (Frankel and Rose, 2002). In general, greater distance involves higher transport costs, and therefore would have an adverse impact on trade. Therefore $\beta_{5}$ should be negative. The population size of the importing country is included as a determinant of demand for $T \& C$ products. Therefore $\beta_{6}$ is expected to be positive. The real exchange rate is a key factor that affects trade flows; the depreciation (appreciation) of the currency of a country against other currencies stimulates (reduces) the exports of a country. Thus, $\beta_{7}$ is expected to be negative.

A number of factors influential to $\mathrm{T} \& \mathrm{C}$ production are considered such as land, labor and capital goods. A higher value of the materials and supplies added in the apparel production should contribute more to the exports. Therefore, $\beta_{8}$ is expected to be positive.

Since trade liberalization has improved after the signing of the Agreement on Textiles and Clothing (ATC) in 2005, price competition among apparel suppliers has become more intense. The amount of the worker wages of the exporters is one of the crucial decisive factors 
in the entire apparel trade flow. Nearly three quarters of the workers who are employed in the global apparel production industry are women. The participation rate of the female labor force in developing countries is even higher. As more female workers are providing a higher production capacity for apparel exports, $\beta_{10}$ is expected to be positive.

In addition to the above macroeconomic factors, the LPI is added as a key independent variable. Exporting countries that share similar factor endowments may differ in their logistics performance in terms of customs clearance efficiency, transport and IT infrastructure quality, ease of arranging international shipments, the ability to track and trace shipments, domestic logistics costs, timeliness in reaching destination, and competence of the domestic logistics industry. It is anticipated that the logistics performance of exporting countries contributes to their apparel exports. Thus, $\beta_{11}$ is expected to be positive.

\section{Data analysis, results and implications}

A pool cross sectional (PCS) or cross sectional (CS) ordinaryleast-square (OLS) is often utilized in the gravity trade model. Unfortunately, Cheng \& Wall ${ }^{21}$ showed that these estimation approaches create biased results. Since there is no heterogeneity allowed in the error term for standard CS regression equations, the gravity trade model produces overestimated results. In order to solve the problem of using the OLS, the panel data estimation method was used to determine the variables that affect the bilateral trade flows among OBOR countries with time. As Baltagi ${ }^{22}$ noted, this method increases the volume of informative data in variability but with less collinearity among the variables. Moreover, the method has more degrees of freedom and efficiency. Finally, the regression results of the OLS were compared with those of the panel data estimation with the fixed effects model in order to examine how well the models fit the data. The data were analyzed by using a panel data analysis and $\mathrm{E}$ Views, a statistical software for econometric analysis.

Historical trade data at the 2-digit Standard International Trade Classification (SITC) level from 2005-2015 were obtained from the United Nations Comtrade Database and Hong Kong Trade Development Council, while data for per-capita GDP, real GDP, population, real exchange rate, etc. were collected from the International Financial Statistics of the International Monetary Fund, Eurostat and other relevant sources. The number of female workers and wages were collected from the Industrial Statistical Database (INDSTAT) from the United Nations Industrial Development Organization (UNIDO), and LPI data were collected from the World Bank.

As shown in Table 1, the extended gravity model is a strong fit for both textile and clothing sectors, with an $\mathrm{R}$ square of 0.67 and 0.76 respectively, and coefficients are significant at 0.01 and 0.05 . The regression results show that $\mathrm{T} \& \mathrm{C}$ exports increase with GDP, GDP per capita of the importing and exporting countries, population of the importing countries, the number of female workers, value added factors and the LPI of exporting countries. Labor wages, distance and real exchange rate have a negative impact on $T \& C$ exports as expected.

The above results imply that $\mathrm{T} \& \mathrm{C}$ trade is expected to grow briskly as a result of growth in the population, GDP, GDP per capita, value added services, and transport-logistics cost in both the trading partner countries in the coming years. This should more than offset the negative impact of wages, with a relatively small effect (as indicated by its coefficient) while the distance does not change and the exchange rates are expected to stabilize in the long term.

Despite the predicted growth implied by the model, the actual growth in T\&C exports should depend on production and investment. The actual trade value also depends on the global demand for $\mathrm{T} \& \mathrm{C}$. The need to expand production capacity and manage demand uncertainty is challenges that $\mathrm{T} \& \mathrm{C}$ companies face in Hong Kong. Investment to expand production capacity takes time and is subjected to risks. Therefore, countries with low labor costs could be potential recipients of foreign direct investment and technological transfer from Hong Kong companies. While the level of IT infrastructure and computer literacy in some of the countries create disadvantages for the competitiveness of the companies in Hong Kong, this is an business and investment opportunity for them, which could have more value added services to the T\&C supply chains. ${ }^{23,9}$

The gravity trade model shows that logistics plays an important role in T\&C exports. ${ }^{24,25}$ This implies that the OBOR initiative which features infrastructure investment projects could have an important role in improving the logistics efficiency of $\mathrm{T} \& \mathrm{C}$ export supply chains and expand their capacity to accommodate high export volume. The initiative is expected to generate social and economic benefits to society and the economy through its positive indirect impacts on other non-infrastructure factors such as logistics performance, customs practices, cultural differences and market information. The seaports in the OBOR countries, which are the nodes in international logistics and supply chains, are expected to play an important part in the initiative. Table 2 shows the capacity of container ports in the OBOR countries. ${ }^{26-53}$

Table I Regression Analysis Result

\begin{tabular}{|c|c|c|}
\hline Dependent Variable: In(EXPij) & Textile & Clothing \\
\hline \multicolumn{3}{|l|}{ Independent Variable } \\
\hline Constant & $-31.12^{* * *}$ & $-25.45 * * *$ \\
\hline $\ln (G D P i)$ & $+1.07 * * *$ & $+1.18^{* * * *}$ \\
\hline $\ln (P C G D P i)$ & $+1.59 * * *$ & $+1.76 * * *$ \\
\hline $\operatorname{Ln}(G D P j)$ & $+2.19 * * *$ & $+2.23 * * *$ \\
\hline Ln(PCGDPj) & $+4.67^{* *}$ & $+4.56^{* *}$ \\
\hline $\ln (\mathrm{Dij})$ & $-1.90 * * *$ & $-1.85 * * *$ \\
\hline $\ln (\mathrm{POPj})$ & $+1.97 * *$ & $+1.89 * *$ \\
\hline REXRATEij & $-1.63 * *$ & $-1.78 * *$ \\
\hline $\ln ($ VALADDEDi) & $+1.19 * * *$ & $+1.23 * * *$ \\
\hline In(WAGEi) & $-0.76 * *$ & $-0.79 * *$ \\
\hline $\ln (\mathrm{FEMALEi})$ & $+0.83 * *$ & $+0.86 * *$ \\
\hline LPli & $+4.24 * * *$ & $+4.53 * * *$ \\
\hline Adjusted $\mathrm{R}^{2}$ & 0.67 & 0.76 \\
\hline
\end{tabular}


Table 2 OBOR Port Information

\begin{tabular}{lllll}
\hline Country & Location & Draught $(\mathbf{m})$ & $\begin{array}{l}\text { Number of Container } \\
\text { Terminals }\end{array}$ & $\begin{array}{l}\text { Capacity (million twenty-foot } \\
\text { equivalent units (TEUs)/year) }\end{array}$ \\
\hline Bangladesh & Chittagong & 8.9 & 11 & 2.34 \\
Cambodia & Sihanoukville & 8.5 & 4 & 0.39 \\
Hong Kong & Kwai Tsing & 15.5 & 9 & 20.07 \\
India & Jawaharlal Nehru & 12.5 & 5 & 4.49 \\
Indonesia & Tanjung Priok & 14 & 3 & 5.2 \\
Malaysia & Klang & 13.4 & 4 & 11.89 \\
Pakistan & Karachi & 11.9 & 1 & 1.56 \\
Philippines & Manila & 13.4 & 2 & 4.23 \\
South Korea & Busan & 17 & 4 & 19.45 \\
Sri Lanka & Columbo & 20 & 8 & 5.19 \\
Taiwan & Kaohsiung & 15 & 6 & 10.26 \\
Thailand & Laem Chabang & 13 & 4 & 6.82 \\
Vietnam & Ho Chi Minh City & 11 & 2 & 5.31 \\
\hline
\end{tabular}

\section{Conclusion}

To conclude, this empirical study has examined the extent to which a number of social and economic factors including transport and logistics performance affect $\mathrm{T} \& \mathrm{C}$ trade between the OBOR countries and Hong Kong, which can serve as the T\&C distribution hub due to its strategic location. The analysis based on the extended trade gravity model shows that GDP, income per capita, distance between countries, population, exchange rates, value added services, labor cost, and the size of the labor workforce are influential to $\mathrm{T} \& \mathrm{C}$ trade.

The findings also indicate that logistics performance plays an important role in trade facilitation which can provide a competitive advantage and thus also constitute as a trade barrier in its own right That is, logistics performance either enhances or reduces the chances of being integrated in global T\&C supply chains. This is especially true for exporting countries in the same geographical region with similar factor endowment. If trade liberalization continues to escalate, large lead buyers will persevere with their global search for the best mix of suppliers to forge their global supply chains. The logistics performance of the exporting countries may become a key determinant in differentiating the winners from losers among the OBOR countries in the global T\&C industries.

The findings imply that there are potential opportunities for Hong Kong T\&C companies to benefit from investing in OBOR countries, transferring technology to them and trading with them. The accumulated knowledge of the T\&C industry in Hong Kong over time allows them to adopt the role of a "super-connector" as the hub or gateway to the global T\&C market. As a hub, Hong Kong would coordinate the production and export logistics and provide high value added services such as product design, and research and development. In terms of investment, Hong Kong companies can establish joint ventures with local $\mathrm{T} \& \mathrm{C}$ producers in the OBOR countries for investment and technology transfer, and make use of its internationally-recognized technical and management knowledge. At the same time, Hong Kong T\&C companies need to manage the risks associated with capacity expansion and global demand uncertainty.

\section{Acknowledgments}

This research is fully supported by a grant from the Research Grants Council of the Hong Kong Special Administrative Region, China (Project No. UGC/FDS25/B01/17).

\section{Conflict of interest}

Author declares there is no conflict of interest in publishing the article.

\section{References}

1. Lau YY, Tam KC, Ng AKY, et al. Effects of the 'Belt and Road' initiative on the wine import logistics of China. Mar Pol \& Man. 2018;45(3):403-417.

2. Celbis MG, Nijkamp P, Poot J. How big is the impact of infrastructure on trade? Evidence from meta-analysis. Technical report, United Nations University, Maastricht Economic and social Research and Training Centre on Innovation and Technology, Working paper, 2013-032. 2013.

3. Hoekman B, Nicita A. Trade policy, trade costs, and developing country trade. Wor Dev. 2011;39(12):2069-2079.

4. Shepherd B, Wilson JS. Trade facilitation in ASEAN member countries: Measuring progress and assessing priorities. $J$ of Asia Econ. 2009;20(4):367-383.

5. Pomfret, R. ASEAN's new frontiers: Integrating the newest members into the ASEAN economic community. Asia Econ Pol Rev. 2013;8(1):25-41.

6. Ross RJ, Chan A. From North-South to South-South: The true face of global competition. For Aff. 2002;81(5):8-13.

7. Liu X, Lovely ME, Ondrich J. The location decisions of foreign investors in China: Untangling the effect of wages using a control function approach. The Rev of Econ \& Stat. 2010;92(1):160-166.

8. Appelbaum R, Bonacich E, Quan K. The End of Apparel Quotas: A Faster Race tothe Bottom?. Santa Barbara: University of California at Santa Barbara; 2005.

9. $\mathrm{Au} \mathrm{KF}, \mathrm{Ho} \mathrm{DCK}$. Electronic commerce and supply chain management: value-adding service for clothing manufacturers. Int Manuf Syst. 2002;13(4):247-255. 
10. Ho DCK. Policies and practices of improving labor welfare of clothing supply chains: A perspective from Hong Kong manufacturers. The First World Congress and 2016 Asia Pacific Decision Sciences Institute Conference, 24-27 July, Beijing, China; 2016.

11. Ho DCK, Lau C. Linking socio-cultural influences to managerial cognition of stake holder salience. Academy of Management 2016 Annual Meeting. 5-9 August. Anaheim, CA; 2016.

12. Ho DCK. A case study of H\&M's strategy and practices of corporate environmental sustainability. Logistics Operations, Supply Chain Management and Sustainability. 2014:241-254.

13. Chan MHE, Au KF, Sarkar MK. Antecedents to India's Textile Exports: 1985-2005. Int J Ind Cult \& Bus.Man. 2008;1(3):265-276.

14. Chan EMH, Chu AWC, Nguyen OHO. Assessing the displacement effect of exports with gravity trade model: China's textile and clothing case and OBOR implications. 2016.

15. Havrylyshin O, Pritchett L. European Trade Patterns after the Transitions. PRE Work ing Paper Series, no.748. Washington, DC: World Bank; 1991.

16. Bayoumi T, Eichengreen B. Is Regionalism Simply a Diversion? Evidence from the Evolution of the EC and EFTA. IMF Working Paper 109. Washington DC, Chicago: University of Chicago Press; 1997:141-168.

17. Anderson J. A Theoretical Foundation for the Gravity Equation. A Econ Rev. 1979;69(1):106-116.

18. Bergstrand JH. The Gravity Equation in International Trade: Some Microeconomic Foundations and Empirical Evidence. Rev of Econ \& Stat. 1985;67(3):474-481.

19. Deardorff AV. Determinants of Bilateral Trade: Does Gravity Work in a Neoclassical World? National Bureau for Economic Research Working Papers Series No. 5377. 1998.

20. Polder M. Forecasting International Trade Flows: A Gravity-Based Approach. Economet Toepass. 2000:24-28.

21. Cheng IH, Wall HJ. Controlling for Heterogeneity in Gravity Models of Trade andIntegration. Fed Res Bank of St Louis Rev. 2005;87(1):49-63.

22. Baltagi BH. Econometric Analysis of Panel Data. 5th ed. NewYork: John Wisely and Sons; 2013. 388 p.

23. Chan MHE, Au KF. Determinants of China's Textiles Export: An analysis bygravity model. J of Text Inst. 2007;98(5):463-469.

24. Au KF, Chan EMH. The impact of social, economic variables and logistics performance on Asian apparel exporting countries. Innovations in Supply Chain Management for Information Systems: Novel Approaches: Novel Approaches. In: Wang J, editor. IGI Global; 2009:204-215.

25. Ho DCK, Chan EMH, Yip TL. A study of countries' logistics performance and export, POMS-HK, The First Production and Operations Management Society - Hong Kong International Conference, 30 December, Hong Kong, China; 2009.

26. Behavioral and Economic Research, Center for Global Studies, Working Paper. 2005.

27. Au KF, Chan MH Eve. Economic, Social and Policy Determinants of EU-5 and American Apparel Imports: A Gravity Model Analysis. Int J Inf Syst \& Sup Chain Man. 2008;1(3):33-48.
28. Azmeh S, Nadvi K. 'Greater Chinese' global production networks in the Middle East: the rise of the Jordanian garment industry. Dev \& Chan. 2013;44(6):1317-1340.

29. BBC. Bangladesh Rana Plaza factory collapse toll passes 600, 2013.

30. Burke J. Bangladeshi workers still missing eight months after Rana Plaza collapse. 2013.

31. Busan Port Authority, Homepage. 2017.

32. Chittagong Port Authority, Homepage. 2017.

33. Greenpeace. New study finds toxic monsters lurking in children's clothing. 2014.

34. Hong Kong Container Terminal Operators Association Limited, Facilities. 2017.

35. Hoskisson RE, Wright M, Filatotchev I, et al. Emerging multinationals from Mid-Range economies: The influence of institutions and factor markets. J of Manage Stud. 2013;50(7):1295-1321.

36. Hong Kong Trade Development Council, One Belt One Road Countries. 2017 .

37. Hutchison Ports KICT. 2017.

38. Lau YY, Chan MH, Nguyen HO. Assessing the displacement effect of exports with gravity trade model: China's textile and clothing case and OBOR implications. $J$ Int Log \& Trade. 2017;15(1);19-32.

39. Laem Chabang Port Authority. 2017.

40. Manila International Container Terminal. 2017.

41. Myint MM, Rasiah R. Foreign capital and garment export from Myanmar: Implications for the labour process. Inst \& Econ. 2012;4(3):151-172.

42. Perry P, Wood S, Fernie J. Corporate social responsibility in garment sourcing networks: Factory management perspectives on ethical trade in Sri Lanka. J of Bus Eth. 2015;130(3):737-752.

43. Port Klang Authority. 2017.

44. Port of Tanjung Priok. 2017.

45. Portugal-Perez, A, Wilson JS. Export performance and trade facilitation reform: Hard and soft infrastructure. Wor Dev. 2012;40(7):1295-1307.

46. Rasiah R, Myint MM. Ownership, technological capabilities and exports of garmentfirms in Myanmar. Tech \& Econ Dev of Econ. 2013;19(1):S22S42.

47. Sihanoukville Autonomous Port. 2017.

48. Sri Lanka Ports Authority. 2017.

49. Taiwan Port Authority. 2017.

50. The Jawaharlal Nehru Port Trust. 2017.

51. Vietnam Seaports Association. 2017

52. Wang $\mathrm{J}, \mathrm{Wu} \mathrm{J}$, Yao X. The expansion of textile and clothing firms of China to Asian Least Developed Countries: The Case of Cambodia. ARTNET Asia-Pacific Research and Training Network on Trade, Working Paper. 2008. 60 p.

53. World Shipping Council. 2017. 